\title{
Mild Thalassemia: the Result of Interactions of Alpha and Beta Thalassemia Genes
}

\author{
Yuet Wai Kan and David G. Nathan \\ From the Division of Hematology of the Department of Medicine of the \\ Children's Hospital Medical Center and the Department of Pediatrics \\ of the Harvard Medical School, Boston, Massachusetts 02115
}

A в S T R A C T Homozygous thalassemia is due to inherited unbalanced synthesis of the $\alpha$ - or $\beta$-chains of hemoglobin. Clinical severity may be in part related to the extent of $\alpha: \beta$ imbalance. Two families are presented that illustrate this concept. Thalassemia in these individuals was evaluated by clinical and genetic criteria. The relative rates of $\alpha$ - and $\beta$-chain synthesis in their reticulocytes were estimated by the extent of incorporation of 1 -leucine- $\mathrm{U}_{-}{ }^{14} \mathrm{C}$ into the chains. $\mathrm{Un}$ usual combinations of clinical and hematological data and biosynthetic ratios were obtained in certain individuals which indicated the presence of combinations of $\alpha$ - and $\beta$-thalassemia genes. The propositus of the first family had mild Cooley's anemia and was believed to have one $\alpha$ - as well as two $\beta$-thalassemia genes. Presumably the $\alpha$-thalassemia gene interfered with $\alpha$-chain production which lead to less accumulation of $\alpha$-chains and a reduced rate of intramedullary and peripheral hemolysis. In the second family two individuals were believed to have an $\boldsymbol{\alpha}$-thalassemia, a "silent carrier," and a $\boldsymbol{\beta}$-thalassemia gene. Despite the fact that they appeared to have the genotype of hemoglobin $\mathrm{H}$ disease, their cells contained no hemoglobin $\mathrm{H}$ and had a normal lifespan presumably because excess $\beta$-chain production was inhibited by the $\beta$-thalessemia gene. These family studies suggest that the $\alpha: \beta$ imbalance observed in thalassemia may be favorably influenced by combinations of $\alpha$ - and $\beta$-thalassemia genes.

\section{INTRODUCTION}

In thalassemia, there is a defect in the synthesis of the normal polypeptide chains of human hemoglobins

This work was presented in part at the Eastern Section Meeting of the American Federation for Clinical Research in Boston, Mass., 6 December 1968 and at the National Meeting of the American Federation for Clinical Research in Atlantic City, N. J., 4 May 1969.

Received for publication 9 April 1969 and in revised form 6 November 1969.
$(1,2)$. In the majority of cases, either the $\alpha$ - or the $\beta$-chain is primarily affected (3-6) resulting in the accumulation of the unaffected chains in the erythroid cells. In homozygous $\beta$-thalassemia, the highly unstable $\alpha$-chains precipitate to form inclusions, found most abundantly in the bone marrow and in the peripheral blood after splenectomy (7-9). In hemoglobin $\mathrm{H}$ disease, the precipitated $\beta$-chains can be demonstrated in the peripheral blood and bone marrow (9-12). The destruction of the erythroid cells in both disorders is believed to be related to these inclusions, which impinge on the red cell membrane, increase cation permeability (13), and also render the cell more liable to be trapped in the reticuloendothelial system of the spleen and other organs $(9,14-16)$. Inclusions of other precipitable hemoglobins have similar effects (17).

If the extent of inclusion formation in thalassemia is related to the degree of globin chain imbalance, a decrease in this imbalance will be expected to produce a milder disease. In $\beta$-thalassemia, such a decrease in imbalance could occur in the following three ways: less inhibition of $\beta$-chain production due to a milder $\beta$-thalassemia gene; an increase in $\gamma$-chain production (18, $19)$; or a decrease in $\alpha$-chain production. In $\alpha$-thalassemia a decrease in imbalance could occur because of a mild $\alpha$-thalassemia gene (6) or the presence of a $\beta$-thalassemia gene.

This paper describes cases of mild thalassemia in which the combination of genetic, hematological, and chain labeling data suggests that both $\alpha$ - and $\beta$-thalassemia genes were present. We propose that the interaction of these genes in certain members of these families produced a decrease in globin chain imbalance and amelioration of their clinical disease.

\section{METHODS}

\section{Patients}

Family $C$. The propositus was a $40 \mathrm{yr}$ old man of Italian descent in whom the diagnosis of homozygous $\beta$-thal- 
TABLE I

Hematological Data and $\beta / \alpha$

\begin{tabular}{|c|c|c|c|c|c|c|}
\hline $\begin{array}{l}\text { Family } \\
\text { members }\end{array}$ & Hemoglobin & Hematocrit & $\begin{array}{l}\text { Red blood } \\
\text { cells } \times 10^{-6}\end{array}$ & Reticulocyte & MCV & $\mathrm{MCH}$ \\
\hline & $\mathrm{g} / 100 \mathrm{ml}$ & $\%$ & per $m^{2}{ }^{2}$ & $\%$ & $\mu^{2}$ & $\mu \mu g$ \\
\hline \multicolumn{7}{|c|}{ Family C } \\
\hline $\mathrm{I}-1$ & 15.2 & 47.1 & 5.34 & 1.3 & 86.0 & 29.1 \\
\hline $\mathrm{I}-2$ & 13.9 & 44.9 & 6.19 & 1.5 & 71.0 & 22.8 \\
\hline $\mathrm{I}-3$ & 15.3 & 48.8 & 5.71 & 1.7 & 84.0 & 27.2 \\
\hline $\mathrm{I}-4$ & 12.7 & 40.4 & 5.20 & 1.5 & 77.5 & 24.4 \\
\hline $\mathrm{I}-5$ & 13.4 & 44.0 & 6.35 & 1.6 & 69.3 & 21.1 \\
\hline II-1 & 13.8 & 40.5 & 4.50 & 0.6 & 90.0 & 30.7 \\
\hline II-2 & 10.0 & 34.5 & 5.86 & 7.2 & 58.0 & 17.0 \\
\hline II-3 & 16.0 & 47.0 . & 5.65 & 1.2 & 83.2 & 28.3 \\
\hline II -4 & 14.8 & 41.5 & 4.70 & 1.5 & 88.3 & 31.5 \\
\hline II-5 & 13.0 & 40.5 & 5.59 & 1.3 & 71.5 & 23.2 \\
\hline III-1 & 13.4 & 41.0 & 6.04 & 1.4 & 67.9 & 22.2 \\
\hline III-2 & 13.4 & 40.0 & 5.74 & 1.8 & 69.7 & 23.3 \\
\hline III-3 & 13.4 & 42.0 & 5.69 & 0.6 & 73.8 & 23.6 \\
\hline III-4 & 12.6 & 38.0 & 5.45 & 1.6 & 69.7 & 23.1 \\
\hline \multicolumn{7}{|c|}{ Family L } \\
\hline I-1 & 10.8 & 40.0 & 7.18 & 0.8 & 55.7 & 15.0 \\
\hline $\mathrm{I}-2$ & 11.6 & 39.0 & 5.88 & 0.3 & 66.3 & 19.7 \\
\hline II-1 & 10.3 & 38.0 & 6.84 & 1.0 & 55.6 & 15.1 \\
\hline II-2 & 11.2 & 38.5 & 5.57 & 1.0 & 69.1 & 20.1 \\
\hline II-3 & Hydrops & & & & & \\
\hline II-4 & 10.4 & 36.0 & 5.44 & 0.4 & 66.2 & 19.2 \\
\hline II-5 & Not studied & & & & & \\
\hline Normal & $14-18$ & $42-52$ & $4.6-6.2$ & $0.8-2$ & $82-92$ & $27-31$ \\
\hline
\end{tabular}

assemia was made at age 20 . His development was normal. $\mathrm{He}$ had hepatosplenomegaly and his hemoglobin ranged from 9 to $11 \mathrm{~g} / 100 \mathrm{ml}$ of blood. Blood transfusion was required once very recently when he had bone marrow hypoplasia after a severe viral infection. His detailed hematological findings and those of his family members are shown in Table I. The life span of his hemoglobins has been previously reported (20).

Family L. A 40 yr old Chinese male complained of chronic cough. No explanation was found for his symptoms but he had mild anemia with severe hypochromia and moderatae splenomegaly. The hemoglobin $\mathrm{A}_{2}$ was elevated and his bone marrow showed erythroid hyperplasia with increased iron stores. ${ }^{51} \mathrm{Cr}$ red cell survival was normal. A complete family study was instituted when this patient's wife produced an infant who died at birth with nonimmunological hydrops fetalis in which there was mainly Bart's hemoglobin (21). The hematological studies in this family are also summarized in Table I.

Seven patients with the severe form of homozygous $\beta$-thalassemia requiring blood transfusion every $6-9 \mathrm{wk}$, and $14 \beta$-thalassemia heterozygotes who were the parents of such patients were also studied.

\section{Experimental}

Blood counts were determined by routine methods (22) and by the use of a Coulter Model S automatic cell counter. ${ }^{1}$

\footnotetext{
${ }^{1}$ Coulter Electronics, Hialeah, Fla.
}

Bone marrow aspirations were obtained from the iliac crest. Hemoglobin $\mathrm{A}_{2}$ was determined by electrophoresis on agarose. ${ }^{2}$ Hemoglobin $\mathrm{F}$ was measured by the method of Singer, Chernoff, and Singer (23).

Globin chain synthesis in blood or bone marrow was measured by the incubation of the heparinized sample with 1 -leucine-U- ${ }^{14} \mathrm{C}$. The chains were separated on carboxymethyl cellulose columns using a gradient elution with a buffer containing $8 \mathrm{M}$ urea and increasing concentrations of sodium phosphatae at $\mathrm{pH} 6.7(24)$. The relative rates of synthesis of $\alpha$ - and $\beta$-chains were expressed by the $\beta / \alpha$ ratio. In the cases of homozygous $\beta$-thalassemia, this ratio was derived from the quotient of the total $\mathrm{cpm}$ in the entire fraction of $\beta$-chain divided by the total cpm in the entire fraction of $\alpha$-chain. A similar method was described by Bank and Marks (5). This quotient theoretically provided an accurate estimate of relative $\alpha$ - and $\beta$ - chain synthesis in this condition and was independent of variations in unlabeled pool size. In the studies of heterozygotes where the count rates were low and the pool sizes were equal, we preferred to compute the $\beta / \alpha$ specific activity ratios of the tubes which contained the peaks of the fractions because the count rates were higher and the purity was maximal. Such considerations were important in samples in which relatively few reticulocytes were present and the incor-

\footnotetext{
${ }^{2}$ Boenisch, T., C. A. Alper, and P. S. Gerald. 1969. Quantitative hemoglobin electrophoresis in agarose gel. Submitted for publication.
} 
Ratios of the Families

\begin{tabular}{|c|c|c|c|c|c|c|}
\hline \multirow[b]{2}{*}{$\mathrm{MCHC}$} & \multirow{2}{*}{$\begin{array}{c}\text { Hemoglobin } \\
\mathbf{A}_{\mathbf{2}}\end{array}$} & \multirow{2}{*}{$\begin{array}{l}\text { Hemoglobin } \\
\text { F }\end{array}$} & \multicolumn{3}{|c|}{$\beta / \alpha$} & \multirow[b]{2}{*}{ Mean } \\
\hline & & & 1 & 2 & 3 & \\
\hline \multicolumn{7}{|l|}{$100 \mathrm{ml}$} \\
\hline 32.9 & 2.0 & 0.4 & 1.05 & 1.02 & - & 1.03 \\
\hline 31.4 & 4.3 & 0.5 & 0.96 & 1.07 & - & 1.01 \\
\hline 31.8 & 1.9 & 0.5 & 1.11 & 1.11 & - & 1.11 \\
\hline 31.4 & 4.2 & 0.6 & 1.10 & 0.96 & - & 1.03 \\
\hline 30.4 & 4.4 & 1.4 & 0.57 & 0.58 & - & 0.58 \\
\hline 34.1 & 2.8 & 0.5 & 1.02 & 0.96 & - & 0.99 \\
\hline 29.0 & 5.9 & 40.0 & 0.49 & 0.41 & - & 0.45 \\
\hline 34.0 & 2.6 & 0.4 & 0.95 & 1.03 & - & 0.99 \\
\hline 35.6 & 2.6 & 0.5 & 0.96 & - & - & 0.96 \\
\hline 32.5 & 4.4 & 0.8 & 0.91 & 0.98 & - & 0.95 \\
\hline 32.7 & 5.2 & 1.7 & 0.53 & 0.57 & - & 0.55 \\
\hline 33.5 & 4.6 & 2.6 & 0.98 & 0.93 & - & 0.95 \\
\hline 31.9 & 4.1 & 1.1 & 1.04 & 0.82 & - & 0.93 \\
\hline 33.1 & 5.2 & 0.8 & 0.63 & 0.60 & - & 0.62 \\
\hline 27.0 & 4.4 & 0.8 & 1.27 & 1.21 & 1.20 & 1.23 \\
\hline 29.7 & 2.3 & 0.5 & 1.28 & 1.29 & 1.36 & 1.33 \\
\hline 27.1 & 4.4 & 1.0 & 1.39 & 1.27 & 1.27 & 1.31 \\
\hline 29.0 & 5.7 & 1.6 & 1.03 & 0.96 & 1.02 & 1.00 \\
\hline 28.9 & 5.7 & 0.66 & 0.69 & 0.68 & 0.68 & 0.68 \\
\hline $32-36$ & $1.9-3.2$ & $<2$ & & & & $0.97 \pm 0.06($ mean $\pm \mathrm{SD})$ \\
\hline
\end{tabular}

poration of labeled leucine into hemoglobin was relatively low (6). The reproducibility of this method is shown in Table II.

In one patient (I-4) of family $\mathrm{C}$ bone marrow was aspirated from the iliac crest into a heparinized syringe. The marrow and a simultaneously obtained peripheral blood sample were treated exactly as described above. Identical amounts of marrow and peripheral blood globin were chromatographed.

\section{RESULTS}

In family C (Table I), the propositus had mild Cooley's anemia with $40 \%$ fetal hemoglobin. His parents (I-4, I-5), one uncle (I-2), his sister (II-5), and all four of his children (III-[1-4]) had $\beta$-thalassemia trait as evidenced by low mean corpuscular volumes (MCV) and mean corpuscular hemoglobins $(\mathrm{MCH})$ and elevated hemoglobin As levels. The hemoglobin F levels were either normal or slightly elevated in these family members. The patient's wife (II-1), two of his uncles (I-1, I-3), and his two brothers (II-3, 4) were normal.

In family $\mathrm{L}$, both parents were at the very least heterozygous for $\alpha$-thalassemia since they produced an hydropic infant (25) and had hypochromia and microcytosis. In addition, we assume that the father also car- ried a $\beta$-thalassemia gene because he had an elevated hemoglobin $A_{2}$ level (2, 26-29). Similarly, all the living children who were examined carried the $\beta$-thalassemia gene. The presence of the $\alpha$-thalassemia gene could not be established in the children using these clinical and genetic data. It is interesting to point out that the red cells of two members of this family (I-1 and II-1) were extremely hypochromic and microcytic. Their MCV and $\mathrm{MCH}$ were considerably lower than the values observed in ordinary $\alpha$ - or $\beta$-thalassemia heterozygotes and were even lower than the values observed in hemoglobin $\mathbf{H}$ disease (Table III).

Table IV presents the $\beta / \alpha$ ratios found after incubation of blood samples of normal individuals and patients with the two forms of $\alpha$-thalassemia trait. These data were obtained in a previous investigation (6). The table also contains the mean $\beta / \alpha$ ratio of 14 patients with $\beta$-thalassemia trait who were parents of homozygotes with severe disease. This value was $0.49 \pm 0.07$ (mean $\pm \mathrm{sD})$. The mean ratio of seven patients with severe

\footnotetext{
${ }^{8}$ In the previous paper, the data were presented as $\alpha / \beta$ specific activity ratios. In this communication, the data are presented as $\beta / \alpha$ ratios.
} 
TABLE II

Reproducibility of $\beta / \alpha$ Ratios Repeated on a Normal Individual, a Patient with Heterozygous $\beta$-Thalassemia, and Two Patients with Heterozygous $\alpha$-Thalassemia

\begin{tabular}{ll}
\hline \multicolumn{1}{c}{ Diagnosis } & \multicolumn{1}{c}{$\beta / \alpha$ ratio } \\
\hline Normal & $1.00,1.02,1.06,1.06,1.05,1.06$ \\
Heterozygous $\beta$-thalassemia & $0.51,0.53,0.52,0.55,0.55$ \\
Heterozygous $\alpha$-thalassemia (A) & $1.29,1.34,1.31$ \\
& (B) \\
& $1.32,1.26$ \\
\hline
\end{tabular}

homozygous $\beta$-thalassemia was 0.09 with a range of $0-0.21$. These results in $\beta$-thalassemia agree well with those of Bank and Marks (5), and Bank, Braverman, O'Donnell, and Marks (30) who used similar methods.

The $\beta / \alpha$ ratios of the $C$ and $L$ families are shown in the last column of Table $\mathrm{I}$. The ratios were determined on two separate occasions in all but one of the members of family $\mathrm{C}$, and on three occasions in all of the members of family $\mathrm{L}$. The individual results and their average values are shown. In family $\mathrm{C}$, all the normal family members (I-1, I-3, II-1, II-3, and II-4) had ratios within the normal range. Of the family members in whom the diagnosis of $\beta$-thalassemia trait was established by clinical criteria, three (I-5, III-1, and III-4) had $\beta / \alpha$ ratios of $0.55-0.62$. These are values within the range obtained in $\beta$-thalassemia heterozygotes. However, the other five members with $\beta$-thalassemia trait (I-2, I-4, II-5, III-2, and III-3) had ratios close to 1 . The propositus in family $\mathrm{C}$ who was homozygous by clinical and genetic criteria had a $\beta / \alpha$ ratio of 0.45 , a value observed in patients heterozygous for $\beta$-thalassemia (Table IV). The chromatogram of his labeled globin is shown in Fig. 1 where it is compared to those of two more severely affected homozygous patients both of whom had significant transfusion requirements. The $\beta / \alpha$ ratios in these severely affected patients were 0 and 0.2 respectively. The significance of these differences is discussed below.

In family L. I-2, the wife of the propositus and the mother of the hydropic infant had a $\beta / \alpha$ ratio of 1.33 compatible with the clinical diagnosis of $\alpha$-thalassemia trait. The findings in the other family members were unexpected. The father, who was presumed to be doubly heterozygous for $\alpha$ - and $\beta$-thalassemia genes, had a ratio
TABLE IV

$\beta / \alpha$ Ratios Obtained on a Group of Patients with Clinically Defined Thalassemia Syndromes

\begin{tabular}{ll}
\hline \multicolumn{1}{c}{ Syndrome } & \multicolumn{1}{c}{$\beta / \alpha$ ratios } \\
\hline Normal* & $0.97( \pm 0.06) \ddagger$ \\
Heterozygous $\beta$-thalassemia $(n=14)$ & $0.49( \pm 0.07) \ddagger$ \\
Homozygous $\beta$-thalassemia $(n=7)$ & $0.09( \pm 0.00-0.21) \S$ \\
Heterozygous $\alpha$-thalassemia* & $1.30( \pm 0.08) \ddagger$ \\
"Silent carrier"* & $1.15( \pm 0.08) \ddagger$ \\
\hline
\end{tabular}

* Values derived from reference 6 , but expressed as $\beta / \alpha$ ratio. $\ddagger$ Mean \pm SD.

$\S$ Mean (range).

of 1.23. The three living children, who had $\beta$-thalassemia trait by clinical criteria, had ratios of $1.31,1.0$, and 0.68 respectively. These last four values will also be discussed below.

The results of simultaneous incubations of the bone marrow and peripheral blood of the father (I-4) of the propositus in family $\mathrm{C}$ are shown in Table $\mathrm{V}$. The specific radioactivity was 20 times higher in the $\alpha$ - and $\beta$-chains of marrow than in peripheral blood, but the $\beta / \alpha$ ratios were not significantly different and approached unity in both samples.

\section{DISCUSSION}

The development of chromatographic methods for separation of the $\alpha$ - and $\beta$-chain of human hemoglobin $(24,31)$ made possible the biochemical evaluation of globin synthesis in $\beta$-thalassemia by Bank and coworkers $(5,30)$, Weatherall, Clegg, and Naughton (4), Heywood, Karon, and Weissman (3), and Weissman, Jeffries, and Karon (32). More recently it has been possible to utilize these methods to establish two forms of $\alpha$-thalassemia genes which account for the four types of $\alpha$-thalassemia (6). The Clegg method $(4,24)$ is reproducible and accurate. Studies of $\beta / \alpha$ ratios performed on a single patient on different occasions produce very similar results (Table II). For this reason it has been possible to apply this technique in the family studies presented here in an attempt to evaluate the presence of interacting thalassemia genes. That such interacting genes may be present in these families is based upon clinical data as well as on the $\beta / \alpha$ ratios.

TABLE III

Red Cell Indices (Mean $\pm \mathrm{SD}$ ) of a Group of Patients with Various Thalassemia Syndromes

\begin{tabular}{lrrrr}
\hline \multicolumn{1}{c}{ Diagnosis } & \multicolumn{1}{c}{$n$} & MCV & MCH & MCHC \\
\hline Heterozygous $\beta$-thalassemia & $(13)$ & $69.7( \pm 3.7)$ & $21.9( \pm 1.3)$ & $31.4( \pm 1.1)$ \\
Heterozygous $\alpha$-thalassemia & $(10)$ & $69.2( \pm 5.0)$ & $22.1( \pm 1.4)$ & $31.7( \pm 1.7)$ \\
$\alpha-\beta$-Thalassemia & $(5)$ & $71.7( \pm 2.4)$ & $23.2( \pm 2.1)$ & $32.1( \pm 1.9)$ \\
Hemoglobin H disease & $(7)$ & $67.2( \pm 4.0)$ & $17.5( \pm 0.8)$ & $36.1( \pm 1.8)$ \\
\hline
\end{tabular}


In family $C$, the inheritance of the $\beta$-thalassemia gene appeared to follow the usual pattern (Fig. 2). The patient inherited a $\beta$-thalassemia gene from each of his parents, and all of this children were hetereozygous for this gene. However, measurements of $\beta / \alpha$ specific activity ratios revealed very unusual results in certain individuals. All of the normal members of the family had ratios close to 1 , as expected. Of the nine individuals with $\beta$-thalassemia trait defined by clinical methods only three had $\beta / \alpha$ ratios within the range found in ordinary $\beta$-thalassemia heterozygotes. The other six
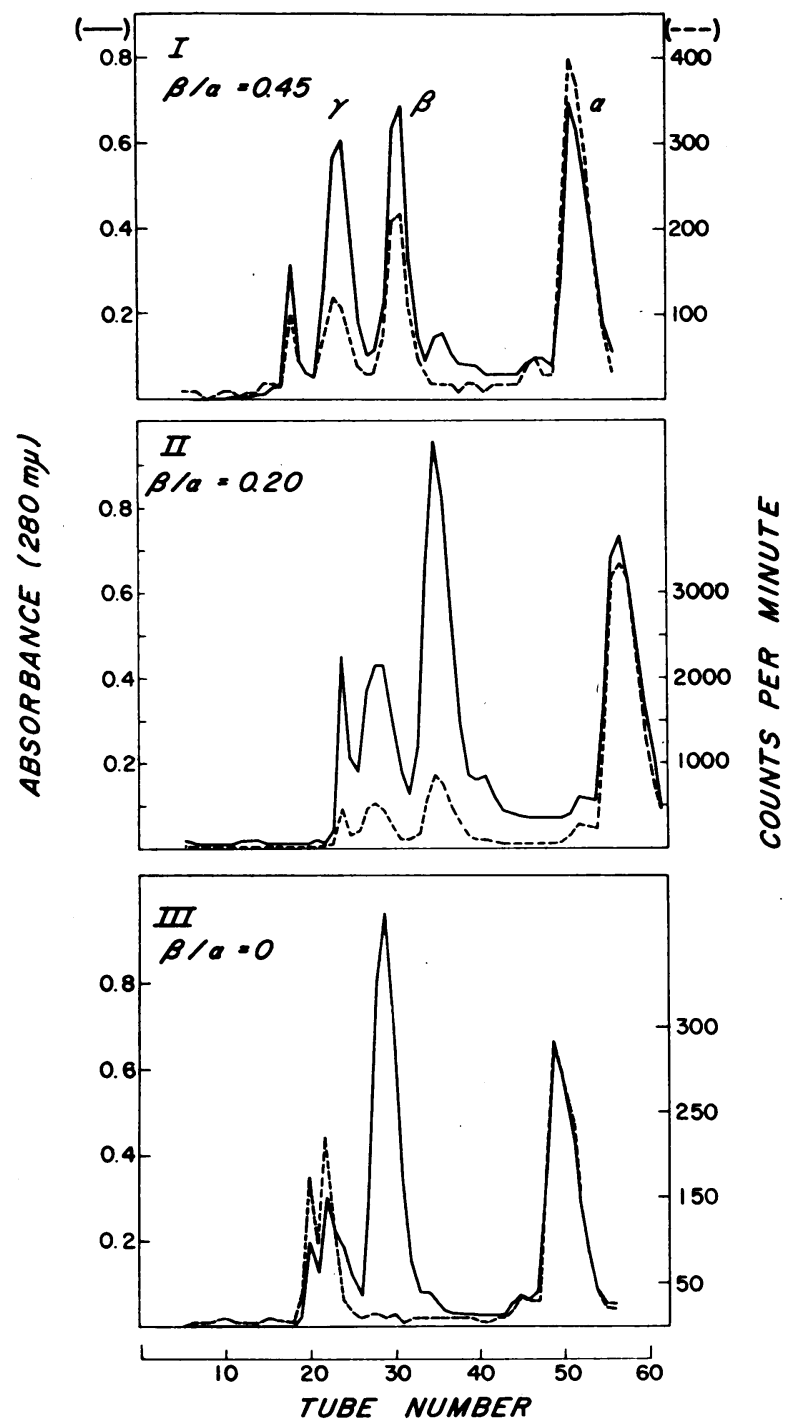

FIGURE 1 Chromatogram of the globin from the propositus of family C (panel I), compared to two other chromatograms of globin from two other patients with severe homozygous $\beta$-thalassemia (panels II and III), who required transfusions. Note that the $\beta / \alpha$ ratio in the propositus is higher.
TABLE V

Chain Labeling in Bone Marrow and Peripheral Blood (Patient I-4, Family C)

\begin{tabular}{|c|c|c|c|c|}
\hline \multirow[b]{2}{*}{ Diagnosis } & \multirow[b]{2}{*}{ Sample } & \multicolumn{2}{|c|}{ Total cpm } & \multirow{2}{*}{$\begin{array}{l}\text { Ratio } \\
\boldsymbol{\beta} / \boldsymbol{\alpha}\end{array}$} \\
\hline & & $\beta$-Chain & $\alpha$-Chain & \\
\hline Proposed $\alpha / \beta$ & PB & $5.22 \times 10^{2}$ & $5.01 \times 10^{2}$ & 1.03 \\
\hline thalassemia & $\mathrm{BM}$ & $1.23 \times 10^{4}$ & $1.12 \times 10^{4}$ & 1.10 \\
\hline
\end{tabular}

PB represents peripheral blood and BM represents bone marrow. The total cpm are calculated by integration of the area under the radiochromatograms.

members had $\beta / \alpha$ ratios which were near unity. Such ratios were within the range of normal and implied that $\alpha$ - and $\beta$-chain synthesis occurred at equal rates in their reticulocytes. This balance of globin chain synthesis in the presence of a $\beta$-thalassemia gene could be explained in three ways. First, the $\beta$-thalassemia gene might be so weak that it does not alter the $\beta / \alpha$ ratio in reticulocytes. Indeed, there is evidence for variability of severity of the $\beta$-thalassemia gene particularly in Negroes (33). However, it is difficult to imagine a thalassemia gene so mild as to be undetectable and yet severe enough to cause a degree of hypochromia and microcytosis equal to that observed in the usual $\beta$-thalassemia trait where the ratio is 0.5 . Indeed, in the $\alpha$-thalassemia syndromes, an abnormal ratio due to a very mild $\alpha$-thalassemia gene (the "silent carrier gene") can be detected by the Clegg method (6). This gene is so mild that it causes no abnormality of morphology. It is unlikely that an even milder $\beta$-thalassemia gene could cause distinct morphologic abnormalities. Secondly, it might be proposed that the $\beta$-thalassemia gene in this family is present only in marrow cells and not in reticulocytes. The hypochromia, microcytosis, and normal ratio could then be explained. But the marrow and peripheral blood studies of the father of the propositus rule out this possibility since the rates of $\alpha$ - and $\beta$-chain production were equal in his marrow as well as in his peripheral blood. Proof of adequate sampling of marrow was obtained from measurements of specific activity in which the globin chains of the marrow sample contained 20 times the radioactivity of peripheral blood globin. A third possibility is the additional presence of an $\alpha$-thalassemia gene. Patients who are thought to be doubly heterozygous for $\alpha_{-}$and $\beta$-thalassemia genes have been detected by the use of clinical and genetic information $(2,26-29)$. We have previously demonstrated a definite decrease in $\alpha$-chain synthesis relative to $\beta$-chain synthesis in the reticulocytes of patients with $\alpha$-thalassemia trait (6). Therefore, patients doubly heterozygous for these traits would be expected to have ratios near unity. 


\section{FAMILY C}

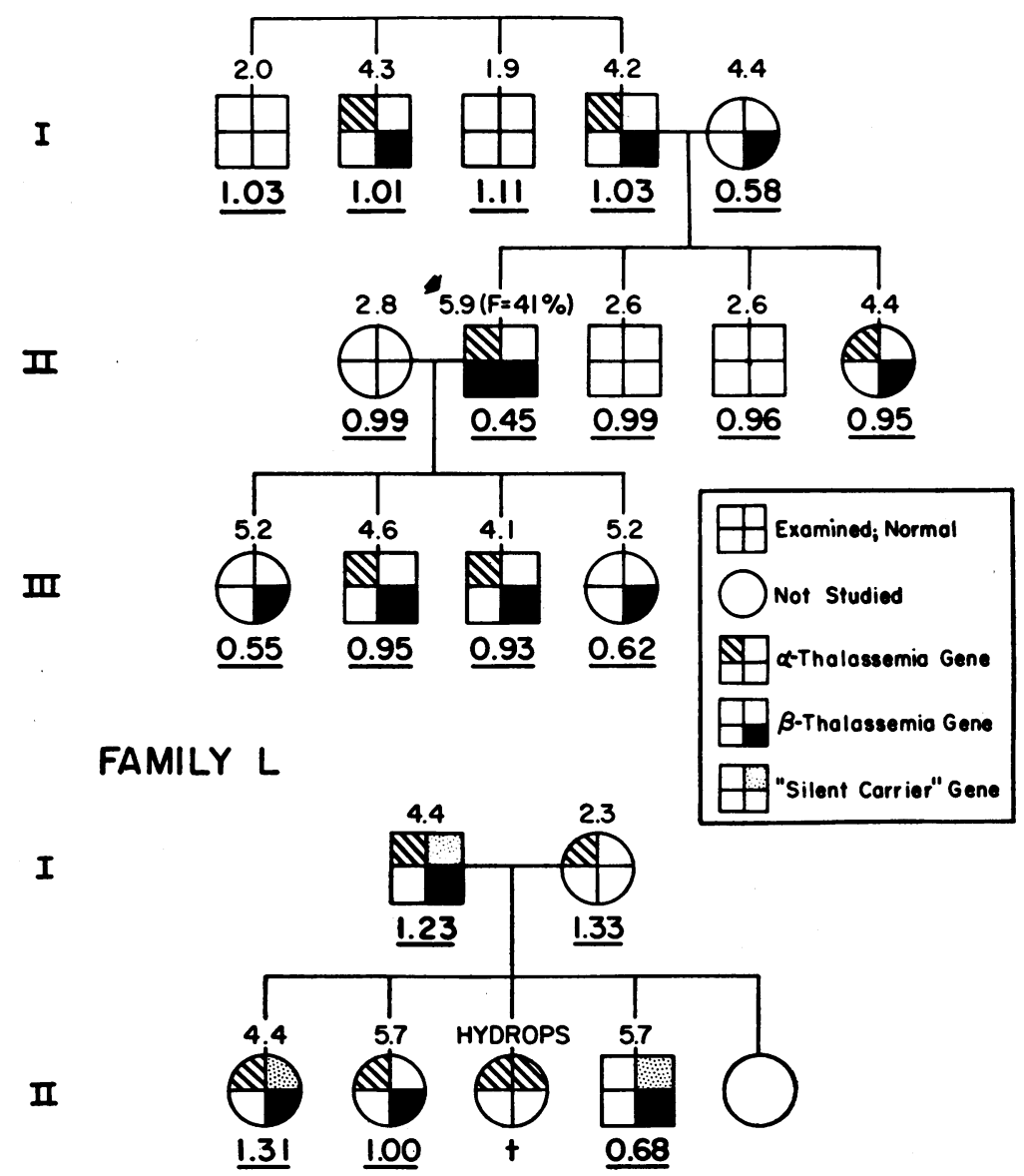

Frgure 2 Pedigrees of family C and family L. The inserted key defines the genotype. The numbers above the symbols represent the per cent of hemoglobin $\mathrm{A}_{2}$ and the numbers below the symbols represent the mean $\beta / \alpha$ ratios.

We conclude that in the five individuals in the $C$ family who have $\beta$-thalassemia by clinical criteria, the $\beta / \alpha$ ratios of unity are best explained by the presence of an additional abnormality, an $\alpha$-thalassemia gene. Abnormalities of $\alpha$ - and $\beta$-chain production cannot be directly determined by incubation of peripheral blood with labeled amino acids because the rate of labeling is closely related to cell age. ${ }^{*}$ Therefore, the $\beta / \alpha$ ratios as well as the clinical data are required to reach this conclusion. Additional support for this conclusion would have been gained had a family member with isolated $\alpha$-thalassemia been observed, but the patients with purported $\alpha$-thalassemia all had an associated $\beta$-thalassemia gene as reflected by the hemoglobin $A_{2}$ concentration.

If the propositus' father and two of his children carried the $\alpha$-thalassemia gene, and his wife was normal, the propositus himself must also have harbored this gene.

\footnotetext{
' Kan, Y. W., and D. G. Nathan. Unpublished observations.
}

On the basis of this reasoning, his genotype must be $\alpha$-, $\beta$-, $\beta$-thalassemia. This conclusion was supported by his $\beta / \alpha$ ratio of 0.45 , a value much higher than those values obtained in patients with ordinary homozygous $\boldsymbol{\beta}$-thalassemia (Table IV).

In family $\mathrm{L}$ (Fig. 2), the wife of the propositus (I-2) had $\alpha$-thalassemia trait established by clinical criteria and measurement of the $\beta / \alpha$ ratio (Table IV) (6). Subject II-2, who had an elevated hemoglobin $A_{2}$ level and a $\beta / \alpha$ ratio of 1 was, therefore, doubly heterozygous for $\alpha_{-}$and $\beta$-thalassemia (vide supra). On the other hand, the propositus (I-1), who was also clinically defined as a double heterozygote for $\alpha$ - and $\beta$-thalassemia, had a $\beta / \alpha$ ratio of 1.23 when the expected ratio was 1 . The technique was sufficiently reproducible and sensitive (Tables II and IV) to differentiate his ratio very certainly from a ratio of 1 . The increased $\beta / \alpha$ ratio must be due either to a higher rate of $\beta$-chain production or 
to a lower rate of $\alpha$-chain production than is ordinarily observed in $\alpha$-, $\beta$-thalassemia. A higher rate of $\beta$-chain production could be due to an unusually mild $\beta$-thalassemia gene. If this were present, the patient's red cell indices would be expected to be no lower than the values observed in patients doubly heterozygous for $\alpha$ - and $\beta$-thalassemia. However, his MCV of $55 \mu^{3}$ and $\mathrm{MCH}$ of $15 \mu \mu \mathrm{g}$ (Table I) were lower than 2 sD below the means of these indices in a large group of patients with $\alpha$-thalassemia trait; $\beta$-thalassemia trait; and $\alpha$-, $\beta$-thalassemia trait (Table III), and he was not iron deficient. The exceptionally low indices do not favor the presence of a weak $\beta$-thalassemia gene but they do support the presence of an additional $\alpha$-thalassemia gene which would also explain the increased ratio. The additional gene could not be an ordinary $\alpha$-thalassemia gene because homozygosity for the usual $\alpha$-thalassemia genes results in the complete suppression of $\alpha$-chain synthesis and death from hydrops fetalis $(21,22,25,34)$. It could be due, however, to the additional presence of a milder $\alpha$-thalassemia gene such as that previously defined as the "silent carrier gene" of hemoglobin $\mathrm{H}$ disease (6). Therefore, we believe that the clinical findings and $\beta / \alpha$ ratio in this individual indicate the presence of the three following thalassemia genes: an $\alpha$-thalassemia, a "silent carrier," and a $\beta$-thalassemia gene. The same genotype can be assigned to II-1, whose findings are identical with those of her father. In II- 4 , the $\beta / \alpha$ ratio of 0.68 is higher than $2 \mathrm{SD}$ above the mean found in a group of patients with $\beta$-thalassemia trait (Table III). The additional inheritance of a "silent carrier gene" together with a $\beta$-thalassemia gene would elevate the $\beta / \alpha$ ratio. Indeed, if the father had both an $\alpha$-thalassemia gene and a "silent carrier gene," and if they are either allelic or closely linked (35), the inheritance of an abnormal $\alpha$-gene by II-4 would be inevitable.

In the propositus of family $\mathrm{C}$, the presence of an $\alpha$-thalassemia gene could have contributed to amelioration of the clinical severity of his homozygous $\beta$-thalassemia because excess $\alpha$-chain production is directly related to inclusion formation (9) and to the rate of destruction of red cells in the $\beta$-thalassemia syndromes (36). Fig. 1 illustrates how the extent of chain imbalance was affected. In this figure, globin chain synthesis in the propositus (panel I) is compared to that of two $\beta$-thalassemia homozygotes who required frequent blood transfusions (panels II and III). Integration of the areas under the radioactivity curves show that the amount of excess $\alpha$-chain production relative to the sum of the production of $\beta$ - and $\gamma$-chains in the propositus is much less than the $\alpha$-radioactivity excess observed in the blood of the severely affected patients. Had the patient shown in panel II inherited an $\alpha$-thalassemia gene, his $\beta / \alpha$ ratio and perhaps his clinical status would have approached that of the propositus. On the other hand, the patient shown in panel III produced no $\beta$-chains at all. His $\beta / \alpha$ ratio could not be altered by a decrease in $\alpha$-chain production, but such a decrease would still result in less excess $\alpha$-chains and, hence, less erythroid cell destruction (36).

In family $\mathrm{L}$, the presence of a $\beta$-thalassemia gene in two individuals who may also have had the genotype of hemoglobin $\mathrm{H}$ disease (6) resulted in a syndrome which was clinically almost indistinguishable from the heterozygous state except for severe hypochromia. Unlike patients with hemoglobin $\mathrm{H}$ disease, these individuals had no excess precipitated hemoglobin and the survival of their red cells in the circulation was normal. These data lend support to the contention that hemolysis in thalassemia is related to the accumulation of uncombined globin subunits $(5,9)$. The suppression of chain synthesis per se which results in hypochromia and microcytosis of the red cells is apparently not responsible for the severe hemolysis in this disease.

The conclusions presented in this report are based upon several different kinds of data. Morphology, hemoglobin electrophoresis, family relationships, and biosynthetic studies have been combined in an effort to provide the most reasonable interpretations. Viewed as a whole, the evidence strongly suggests that three thalassemia genes may combine in one individual to produce a relatively mild form of the disease.

\section{ACKNOWLEDGMENTS}

The authors are grateful for the continued excellent technical assistance of Rebecca M. Tiedemann. Dr. Granville Nickerson, Dr. Bernard Cooper, Dr. Nannie deLeeuw, and Dr. Rhoda Blostein, Royal Victoria Hospital, Montreal, Canada made possible the study of the $L$ family.

This work was supported by U. S. Public Health Service Grant HD 02777 and by a grant from the John A. Hartford Foundation. Dr. Nathan is the recipient of U. S. Public Health Service Research Career Development Award 5 KO3 AM35361. Some of these studies were performed in U. S. Public Health Service Clinical Research Centers supported by grants FR-00128 and 5-MO1-FR 3109.

\section{REFERENCES}

1. Ingram, V. M., and A. O. W. Stretton. 1959. The genetic basis of the thalassemia diseases. Nature (London). 184: 1903.

2. Fessas, Ph. 1965. Forms of thalassemia. In Abnormal Haemoglobins in Africa : a CIOMS Symposium. J. H. P. Jonxis, editor. Blackwell Scientific Publications Ltd., Oxford. 71.

3. Heywood, J. D., M. Karon, and S. Weissman. 1964. A difference in the incorporation of radioactive amino acids into hemoglobin by normal and thalassemic reticulocytes. Science (Washington). 146: 530.

4. Weatherall, D. J., J. B. Clegg, and M. A. Naughton. 1965. Globin synthesis in thalassemia: an in vitro study. Nature (London). 208: 1061. 
5. Bank, A., and P. A. Marks. 1966. Excess alpha chain synthesis relative to beta chain synthesis in thalassemia major and minor. Nature (London). 212: 1198.

6. Kan, Y. W., E. Schwartz, and D. G. Nathan. 1968. Globin chain synthesis in the alpha thalassemia syndromes. J. Clin. Invest. $47: 2515$.

7. Fessas, $\mathrm{Ph}$. 1963. Inclusions of hemoglobin in erythroblasts and erythrocytes of thalassemia. Blood J. Hematol. $21: 21$.

8. Fessas, Ph., D. Loukopoulos, and A. Kaltsoya. 1966. Peptide analysis of the inclusions of erythroid cells in beta-thalassemia. Biochim. Biophys. Acta. 124: 430.

9. Nathan, D. G., and R. B. Gunn. 1966. Thalassemia: the consequences of unbalanced hemoglobin synthesis. Amer. J. Med. $41: 815$.

10. Rigas, D. A., R. D. Koler, and E. E. Osgood. 1956. Hemoglobin $\mathrm{H}$. Clinical laboratory and genetic studies of a family with a previously undescribed hemoglobin. J. Lab. Clin. Med. $47: 51$.

11. Gouttas, A., P. Fessas, H. Tsevrenis, and E. Xefteri. 1955. Description d'une nouvelle variété d'anémia hemolytique congénitale. Sang. 26: 911.

12. Fessas, $\mathrm{Ph}$., and $\mathrm{X}$. Yataghanas. 1968. Intraerythroblastic instability of hemoglobin $\beta_{4}(\mathrm{Hgb} \mathrm{H})$. Blood J. Hematol. $31: 323$.

13. Nathan, D. G., T. B. Stossel, R. B. Gunn, H. S. Zarkowsky, and M. T. Laforet. 1969. Influence of hemoglobin precipitation on erythrocyte metabolism in alpha and beta thalassemia. J. Clin. Invest. 48: 33 .

14. Rifkind, R. A. 1966. Destruction of injured red cells in vivo. Amer. J. Med. 41: 711 .

15. Slater, L. M., W. A. Muir, and R. I. Weed. 1968. Influence of splenectomy on insoluble hemoglobin inclusion bodies in beta thalassemic erythrocytes. Blood $J$. Hematol. 31: 766.

16. Wennberg, E., and L. Weiss. 1968. Splenic erythroclasia: an electron microscopic study of hemoglobin $\mathrm{H}$ disease. Blood J. Hematol. 31: 778.

17. Jacob, H. S., M. C. Brain, and J. V. Dacie. 1968. Altered sulfhydryl reactivity of hemoglobin and red blood cell membranes in congenital Heinz body hemolytic anemia. J. Clin. Invest. $47: 2664$.

18. Gabuzda, T. G., D. G. Nathan, and F. H. Gardner. 1964. Thalassemia trait: genetic combinations of increased fetal and $\mathrm{A}_{2}$ hemoglobins. N. Engl. J. Med. 270: 1212.

19. Fessas, $\mathrm{Ph}$. 1962. $\beta$ chain thalassemia. In HaemoglobinColloquim Wien. H. Lehmann and K. Betke, editors. Thieme Verlag KG., Stuttgart. 90.

20. Gabuzda, T. G., D. G. Nathan, F. H. Gardner. 1963. The turnover of hemoglobins $\mathrm{A}, \mathrm{F}$, and $\mathrm{A}_{2}$ in the peripheral blood of three patients with thalassemia. $J$. Clin. Inv'est. 42 : 1678.
21. Kan, Y. W., A. Allen, and L. Lowenstein. 1967. Hydrops fetalis with alpha thalassemia. N. Engl. J. Med. 276: 18.

22. Cartwright, G. E. 1964. Diagnostic Laboratory Hematology. Grune \& Stratton Inc., New York. 3rd edition.

23. Singer, K., A. I. Chernoff, and L. Singer. 1951. Studies on abnormal hemoglobins. II. Their identification by means of fractional hemoglobins. Blood J. Hematol. 6: 429.

24. Clegg, J. B., M. A. Naughton, and D. J. Weatherall. 1965. An improved method for the characterization of human haemoglobin mutants : identification of $\alpha_{2} \beta_{2}{ }^{85} \mathrm{GLU}$ haemoglobin $\mathrm{N}$ (Baltimore). Nature (London). 207: 945.

25. Lie-Injo, Luan Eng, Lie Hong Gie, J. A. M. Ager, and H. Lehmann. 1962. Alpha-thalassemia as cause of hydrops fœetalis. Brit. J. Haematol. 8: 1.

26. Bütikofer, Von E., R. Hoigné, H. R. Marti, and K. Betke. 1960. Hämoglobin-H-Thälassamie. Schweiz. Med. Wochenschr. 90: 1215.

27. Pearson, H. A. Alpha-beta thalassemia disease in Nego family. 1966. N. Engl. J. Med. 275: 176.

28. Todd, D., M. Lai, and C. A. Braga. 1967. Thalassemia and hydrops foetalis-family studies. Brit. Med. J. 3 : 347.

29. Todd, D., M. C. S. Lai, C. A. Braga, and H. N. Soo. 1969. Alpha-thalassemia in Chinese: cord blood studies. Brit. J. Haematol. 16: 551 .

30. Bank, A., A. S. Braverman, J. V. O'Donnell, and P. A. Marks. 1968. Absolute rate of globin synthesis in thalassemia. Blood J. Hematol. 31: 226.

31. Chernoff, A. I. 1961. The amino acid composition of hemoglobin. I. An improved method for separating the peptide chains of human hemoglobins. J. Chromatogr. 6: 252.

32. Weissman, S. M., I. Jeffries, and M. Karon. 1961. The synthesis of alpha beta and delta chains by reticulocytes from subjects with thalassemia or hemoglobin Lepore. J. Lab. Clin. Med. $69: 183$.

33. Weatherall, D. J. 1964. Biochemical phenotypes of thalassemia in the American Negro population. Ann. N. Y. Acad. Sci. 119: 450.

34. Nathan, D. G., P. S. Gerald, S. Driscoll, and J. M. Craig. 1966. Hydrops fetalis and erythroblastosis in homozygous alpha thalassemia. Abstract from the Meeting of the Society for Pediatric Research, Atlantic City, N. J.

35. Wasi, P., S. Na-Nakorn, and A. Suingdumrong. 1964. Haemoglobin $\mathrm{H}$ in Thailand: a genetic study. Nature (London). 204: 907

36. Vigi, V., S. Volpato, D. Gaburro, F. Conconi, A. Bargelles, and S. Pontremoli. 1969. The correlation between red-cell survival and excess of $\alpha$-globin synthesis in $\beta$-thalassemia. Brit. J. Haematol. 16: 25. 